\title{
PENERAPAN ALGORITMA APRIORI PADA SISTEM REKOMENDASI BARANG DI MINIMARKET BATOX
}

\author{
Nur Fitrina ${ }^{1)}$; Kustanto ${ }^{2)}$; Retno Tri Vulandari ${ }^{3)}$ \\ 1)2)3) Program Studi Teknik Informatika, STMIK Sinar Nusantara \\ ${ }^{1)}$ missfitrina@gmail.com; ${ }^{2)}$ kustanto@sinus.ac.id ; ${ }^{3)}$ retnotv@sinus.ac.id
}

\begin{abstract}
Recommendations are the result of observation, data processing, and decision making in purchasing multiple products simultaneously. In processing large data the right method is needed. Association rules are one of the techniques in data mining, this method can produce patterns of relationships indirectly from a number of data. The purpose of this study is a system for purchasing goods, most likely from each combination of goods purchases. The research method used is direct interview to obtain information in the form of sales data and system requirements. The design model uses the System Development Life Cycle (SDLC). The system design method used is the Unified Modeling Language (UML). The goods recommendation system with a priori algorithm is made web-based using the PHP programming language and MySQL as a database. The results achieved in this study are a combination of 2 item sets with a minimum support of $30 \%$ and minimum confidence of $70 \%$.
\end{abstract}

Keywords: Recommendations, Association Rule, Apriori Algorithm.

\section{PENDAHULUAN}

Sebuah bisnis akan selalu membutuhkan sebuah informasi. Kemampuan mengolah data menjadi informasi sangatlah diperlukan. Kecepatan informasi yang diperoleh sebuah perusahaan dapat memberikan keuntungan dalam menyusun sebuah strategi bisnis yang efektif dan efisien, salah satu keuntungan adanya kecepatan informasi adalah adanya system rekomendasi. Adanya persaingan yang ketat merupakan salah satu dampak kemajuan Teknologi Informasi. Banyaknya pasar modern yang semakin bermunculan menambah tingkat kompetisi dalam persaingan pasar dalam melayani kebutuhan konsumen. Dari hal tersebut maka setiap usaha harus memiliki strategi bisnis yang dirancang sedemikian rupa agar tetap bertahan dalam persaingan pasar. Salah satu strategi adalah mengenai ketersediaan stok barang yang sesuai dengan kebutuhan konsumen.

Minimarket Batox salah satu unit yang berkecimpung di dalam dunia bisnis jual-beli yang menyediakan segala kebutuhan seharihari masyarakat yang berdiri dari tahun 2006. Kendala yang sering dihadapi oleh Minimarket Batox terkait mengenai stok. Minimarket Batox mengalami kendala dalam jenis persediaan barang. Karena kekurangan persediaan jenis stok barang maka akan berdampak pada kekecewaan konsumen.
Pada Minimarket Batox setiap transaksi dicatat dalam sistem dan disimpan dalam database sistem. Dari data tersebut dapat dihasilkan sebuah informasi baru berupa sistem rekomendasi barang terkait yang sering dibeli konsumen. Salah satu metode yang dapat menyelesaikan masalah tersebut adalah association rule apriori, metode ini dapat menghasilkan kombinasi item yang ada pada transaksi pembelian [1].

Hasil dari penelitian ini adalah sistem rekomendasi barang dengan metode algoritma apriori dalam pengambilan keputusan di minimarket Batox..

\section{TINJAUAN PUSTAKA}

\subsection{Algoritma Apriori}

Penggalian data yang banyak membutuhkan algoritma yang tepat. Algoritma apriori adalah salah satu algoritma pengambilan data dengan aturan asosiasi (Association rule) untuk menentukan hubungan asosiasi suatu kombinasi item [2]. Aturan yang menyatakan asosiasi terhadap beberapa atribut seringkali disebut market basket analysis atau affinity analysis. Cara kerja atau tahapan kerja dari Algoritma Apriori dijelaskan pada Gambar 1. 


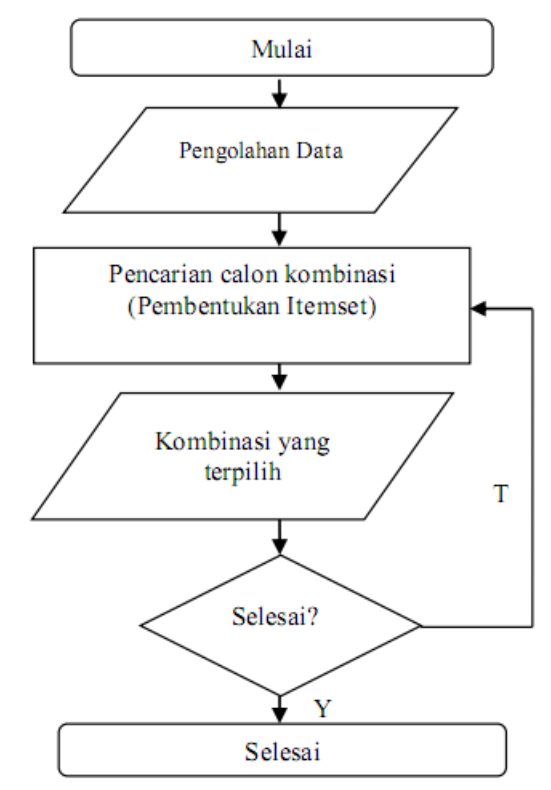

Gambar 1 Flowchart Algoritma Apriori

Tiap iterasi menghasilkan pola frekuensi tinggi dengan panjang yang sama dimulai dari iterasi pertama yang menghasilkan pola frekuensi tinggi dengan panjang satu. Berikut tahapan algoritma apriori [3] :

1. Pencarian kandidat itemset (k-itemset).

2. Penetapan pola frekuensi tinggi. Kriteria item yang termasuk dalam pola frekuensi tinggi adalah item dengan support melebihi dari ketentuan minimal support.

Jika tidak diperoleh pola frekuensi tinggi baru maka seluruh proses dihentikan dan kembali ke tahapan awal.

\subsection{Studi Literatur}

Sistem Rekomendasi Penelusuran Buku dengan Penggalian Association Rule menggunakan Algoritma Apriori. Transaksi peminjaman buku di Badan Perpustakaan dan Kearsipan Provinsi Jawa Timur. LangkahLangkah penelitian adalah mencari data peminjaman buku di Badan Perpustakaan dan Kearsipan Provinsi Jawa Timur, mengolah data sesuai sistem rekomendasi penelusuran buku yang berisi kode buku, nama buku, menghitung generate rule dengan apriori yang sebelumnya menentukan minimal support dan minimal confidence, pembuatan sistem dengan penerapan apriori, pengujian dengan pembuatan grafik waktu eksekusi support dan confidence. Hasil penelitian ini berupa asosiasi antar buku, sebagai dasar rekomendasi alternatif peminjaman buku, yang didapatkan dari perhitungan minsup dan minconf (dengan data yang digunakan sebanyak $63 \%$ dari data transaksi tahun 2009- 2012). Data yang akan di uji memiliki persebaran yang tidak seimbang, cenderung pada transaksi dengan satu atau dua buku saja, sehingga rekomendasi yang ditemukan algoritma sedikit. Kelebihan adalah waktu eksekusi lebih cepat karena menerapkan perhitungan apriori sehingga tidak perlu melihat catatan peminjaman dahulu.[4]

Data transaksi penjualan obat pada Apotek Musi dengan metode Apriori. Hasil penelitian adalah terbentuknya suatu sistem pendukung keputusan yang dapat menentukan prediksi pola pembelian obat di Apotek Musi. Kekurangan adalah tidak dijelaskan secara lengkap bagaimana pembuatan sistem. Kelebihan adalah pengetahuan baru yang dapat diperoleh berdasarkan hasil perhitungan algoritma apriori dan sistem yang dibangun dapat dilakukan pengaturan tata letak obat secara berdekatan untuk memudahkan keberadaan obat [5].

Metode association rule dengan algoritma Apriori yang dapat menemukan kombinasi item yang ada pada transaksi penjualan. Kombinasi item yang dihasilkan dari proses Apriori ini kemudian akan digunakan sebagai bahan rekomendasi strategi promosi penjualan yang berupa pembentukan paket belanja. Hasil dari penelitian ini berupa sistem informasi yang menghasilkan pembentukan paket belanja. [6]

\section{METODE PENELITIAN}

Dalam metode penelitian ini menggunakan System Development Life Cycle (SDLC) yaitu Analisa, Desain, Konstruksi, Implementasi, dan Pengujian.

\subsection{Analisa}

Analisa dilakukan untuk mengetahui kebutuhan sistem. Dalam analisa dilakukan pengumpulan data sebagai sumber penelitian dengan tahapan sebagai berikut :

1. Pengumpulan Data

Metode ini digunakan untuk mengumpulkan data mengenai Minimarket Batox dan data yang dibutuhjan sistem. Data yang digunakan adalah data penjualan produk dengan data testing 30 transaksi data training berjumlah 100 transaksi. Selain itu, penelitian ini menggunakan metode pengumpulkan data pustaka. Data diambil dari mempelajari buku refrensi, mencari sumber yang berkaitan dengan penelitian baik dari internet maupun jurnal skripsi.

2. Pengolahan Data 
Data yang di dapat dari data transaksi kemudian diolah agar menghasilkan data training. Langkah pertama adalah proses pembersihan data dengan mencari data yang memiliki sedikit kesalahan data atau clean data. Setelah menjadi data training, data tersebut dapat digunakan untuk perhitungan dengan metode Apriori [7].

\subsection{Desain Sistem}

Tahapan selanjutnya merupakan desain sistem. Dalam melakukan desain sistem dirancang dengan permodelan Unified Modeling Languange (UML). Setelah perancangan, kemudian membuat desain sistem dimana terdiri dari desain database, desain input, dan desain output [8].

\subsection{Konstruksi}

Tahapan pembuatan sistem ini merupakan tahapan dimana rancangan atau cetak biru sistem ini mulai dikerjakan dan dibuat menjadi sebuah sistem yang utuh, dan dapat digunakan. Dalam penelitian ini menggunakan bahasa pemrograman PHP dan MySql sebagai database.

\subsection{Implementasi}

Tahapan ini merupakan tahapan dimana sebuah sistem sudah diimplementasikan dibuat, Pada tahapan ini sistem diimplementasikan dengan menggunakan Algoritma Apriori.

\subsection{Pengujian}

Pengujian aplikasi dilakukan dengan metode black box dan uji validitas. Pengujian black box adalah pengujian aspek fungsional program. Sedangkan pengujian validitas lebih dilakukan uji mengenai perhitungan algoritma itu sendiri yaitu algoritma apriori. Selain itu dilakukan uji di Minimarket Batox dengan membandingkan rekomendasi sistem dengan data pembelian barang pada periode tertentu sehingga dapat diketahui seberapa validitas sistem.

\section{HASIL DAN PEMBAHASAN}

Pada penelitian ini data training yang diambil berupa 100 data transaksi penjualan produk. Data training terdiri dari nomor faktur penjualan, kode barang, nama barang. Kemudian langkah kedua dilakukan pencarian Frequency Item.

Data training dikelompokan sesuai jenis barang dan direpresentasikan dalam bentuk biner. Dari data training didapatkan 118 item.

Pencarian kandidat pertama dengan menentukan nilai support pada item pada calon kandidat pertama dengan rumus pencarian support. Support adalah nilai persentase kombinasi sebuah item dalam database dan confidence adalah kuatnya hubungan keterkaitan antar item dalam database.

$$
\text { Support }(A)=\frac{\Sigma \text { Transaksi item A }}{\Sigma \text { Transaksi }}
$$

Kemudian memilih item yang memiliki support lebih dari minimal support yang telah ditentukan yaitu $30 \%$ sebagai kandidat pertama. Berikut kandidat pertama dan nilai support terdaftar dalam Tabel 1.

\section{Tabel 1 Kandidat Pertama}

\begin{tabular}{|l|l|l|}
\hline Daftar Item & Jumlah & Support \\
\hline Cofemix20g & 44 & $44.00 \%$ \\
\hline Gula Pasir 1kg & 47 & $47.00 \%$ \\
\hline Indomie Goreng & 30 & $30.00 \%$ \\
\hline $\begin{array}{l}\text { Sedap Kuah Ayam } \\
\text { Bawang }\end{array}$ & 43 & $43.00 \%$ \\
\hline Teh Nyapu Pack 40g & 44 & $44.00 \%$ \\
\hline Telur Kiloan & 39 & $39.00 \%$ \\
\hline
\end{tabular}

Langkah selanjutnya adalah pencarian kandidat kedua. Pencarian kandidat kedua dengan mengkombinasikan item dari kandidat pertama. Sehingga didapatkan item yang berpasangan.Jika kombinasi yang digunakan lebih dari satu maka cara untuk menemukan support dari dua item yaitu item $A$ dan item $B$ digunakan rumus berikut [9].

$$
\text { Support }(A \cap B)=\frac{\Sigma \text { Transaksi item } A \cap B}{\Sigma \text { Transaksi }}
$$

Pencarian nilai support dengan kombinasi dua item dilihat dari Tabel 2.

\section{Tabel 2 Kandidat Kedua}

\begin{tabular}{|l|l|l|}
\hline Daftar Item & Jumlah & Support \\
\hline Cofemix 20g,Gula pasir 1kg & 32 & $32.00 \%$ \\
\hline
\end{tabular}

Iterasi berhenti pada kombinasi kedua karena item yang memenuhi syarat minimal support hanya satu kombinasi. Dari kombinasi tersebut dapat dibentuk aturan asosiasi sebagai berikut :

$$
\begin{aligned}
& \{\text { Cofemix }\} \rightarrow\{\text { Gula Pasir }\} \\
& \{\text { Gula Pasir }\} \rightarrow \text { \{Cofemix }\}
\end{aligned}
$$

Dari aturan asosiasi tersebut dicari confidence masing-masing dan diseleksi berdasarkan minimal confidence yang 
ditetapkan. Confidence yang merupakan ukuran ketepatan suatu rule yang terkandung dalam Item A dan Item B dapat menggunakan rumus berikut [9] .

$$
\text { Confidence }(B \mid A)=\frac{\Sigma \text { Transaksi item A } \cap \mathrm{B}}{\Sigma \text { Transaksi A }}
$$

Confidence tiap aturan asosiasi dapat dilihat pada Tabel 3 .

Tabel 3 Nilai Confidence

\begin{tabular}{|l|l|l|}
\hline Anticedent & Consequent & Confidence \\
\hline Cofemix $20 \mathrm{~g}$ & Gula Pasir $1 \mathrm{~kg}$ & $73.00 \%$ \\
\hline Gula Pasir $1 \mathrm{~kg}$ & Cofemix $20 \mathrm{~g}$ & $68.00 \%$ \\
\hline
\end{tabular}

Dari nilai confidence tiap kombinasi, aturan asosiasi yang memenuhi syarat minimal confidence sebesar $70 \%$ hanya 1 yaitu aturan asosiasi pertama dengan nilai confidence $73.00 \%$.

\subsection{Use Case Diagram}

Use case diagram mempresentasikan sebuah interaksi antar aktor dengan sistem, berikut ini adalah use case diagram sistem rekomendasi barang dengan algoritma apriori seperti yang terlihat pada Gambar 3.

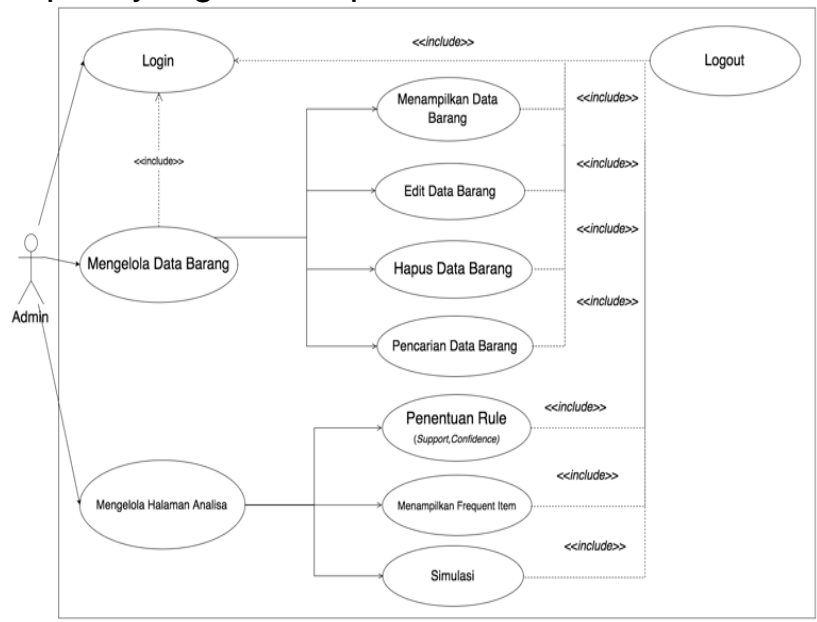

\section{Gambar 2 Use Case Diagram Sistem Rekomendasi Barang}

\subsection{Class Diagram}

Class diagram menggambarkan keadaan (atribut atau properti) suatu sistem, sekaligus menawarkan layanan untuk memanipulasi keadaan tersebut (metode atau fungsi). Berikut adalah class diagram sistem rekomendasi barang dengan algoritma apriori seperti yang terlihat pada Gambar 4.

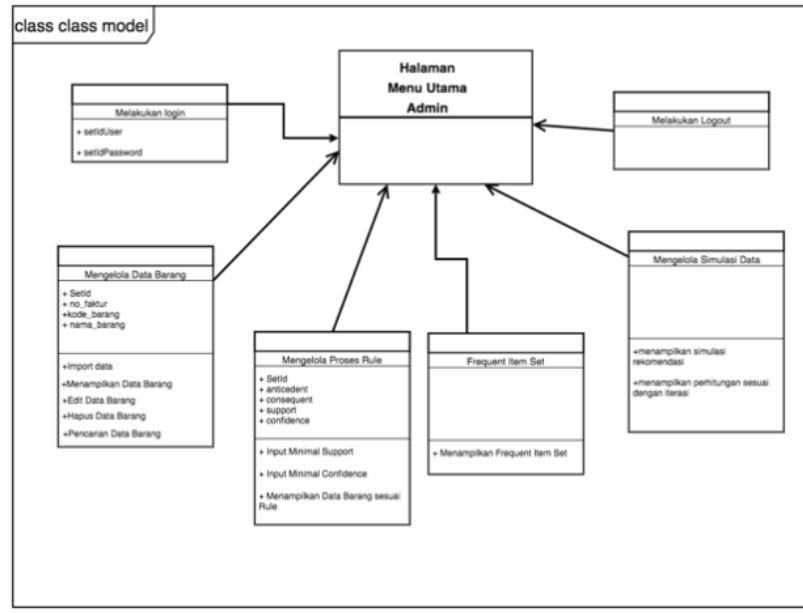

Gambar 3 ClassDiagram Sistem Rekomendasi Barang

\subsection{Sequence Diagram}

Sequence diagram menjelaskan interaksi objek yang berdasarkan urutan waktu atau tahapan yang harus dilakukan. Berikut Sequence Diagram perhitungan apriori :

1. Sequence diagram untuk mengelola proses rule menghasilkan aturan asosiasi dengan apriori.

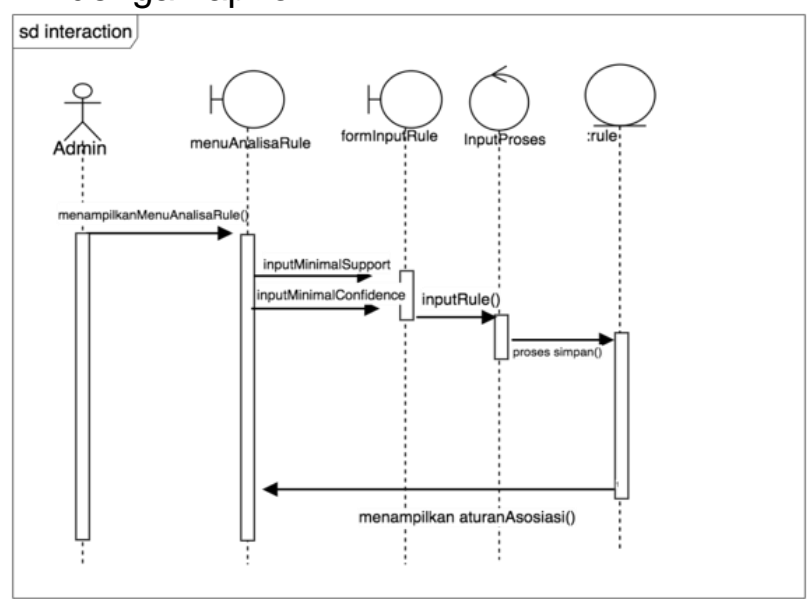

Gambar 4 Sequence Diagram Proses Rule

2. Sequence diagram pencarian Frequency Item

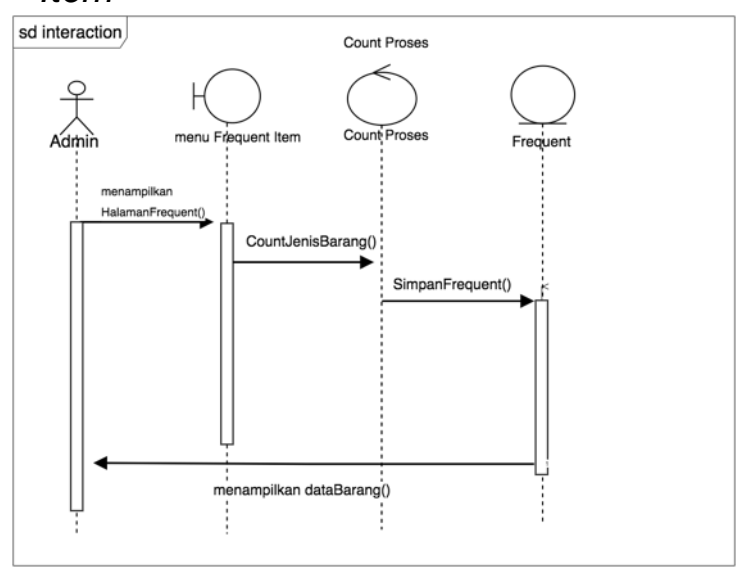




\section{Gambar 5 Sequence Diagram pencarian frequent item}

3. Sequence diagram simulasi aturan asosiasi

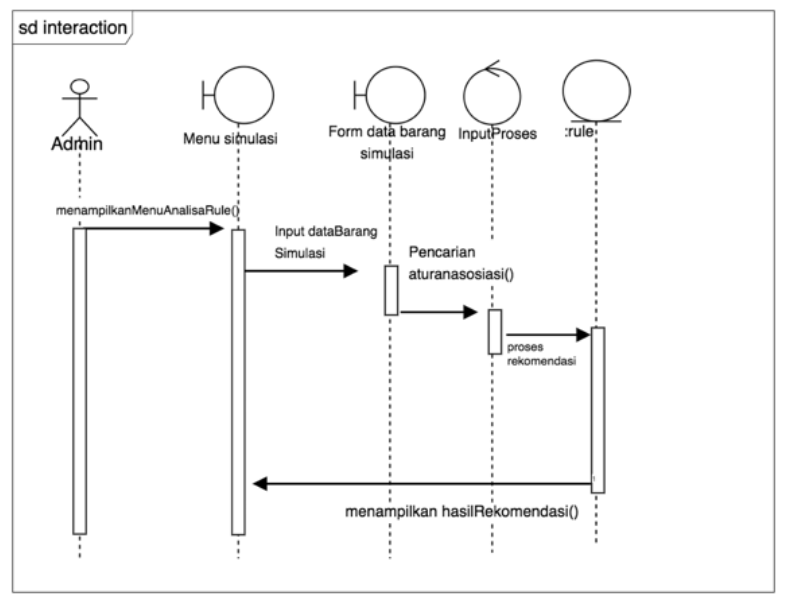

\section{Gambar 6 Sequence Diagram Simulasi}

\subsection{Activity Diagram}

Activity Diagram menggambarkan berbagai alir aktivitas dalam sistem yang sedang dirancang, bagaimana masing-masing alir berawal, decision yang mungkin terjadi, dan bagaimana mereka berakhir [10]. Berikut activity diagram perhitungan apriori dan simulasi pada Gambar 8.

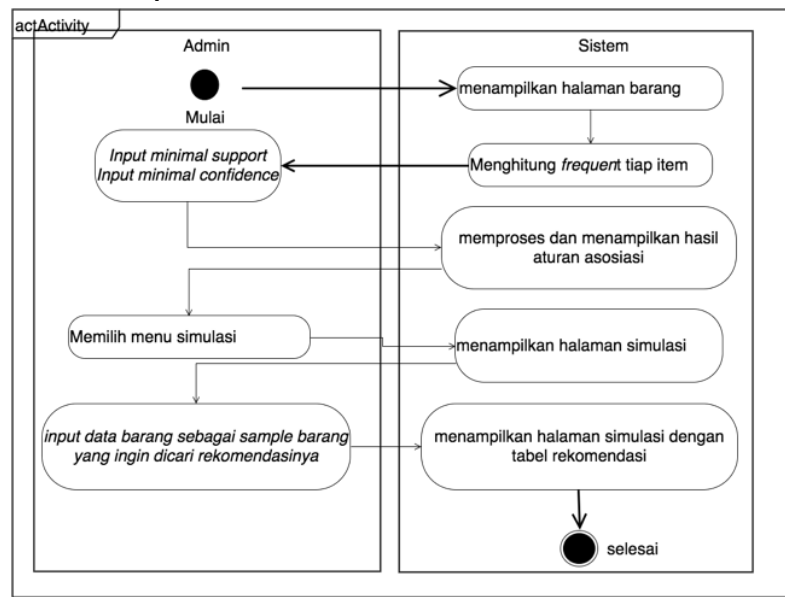

Gambar 7 Activity Diagram Apriori

\subsection{Implementasi}

Implementasi dari sistem rekomendasi barang dengan algoritma apriori dapat dijelaskan sebagai berikut:

1. Desain Halaman Rule dan Simulasi Rekomendasi

Pada halaman ini akan menampilkan data input rule dan aturan asosiasi hasil generate rule. Pada halaman simulasi ditampilkan bagaimana simulasi rekomendasi barang sesuai barang yang dipilih seperti yang terlihat pada Gambar 11 dan Gambar 12.

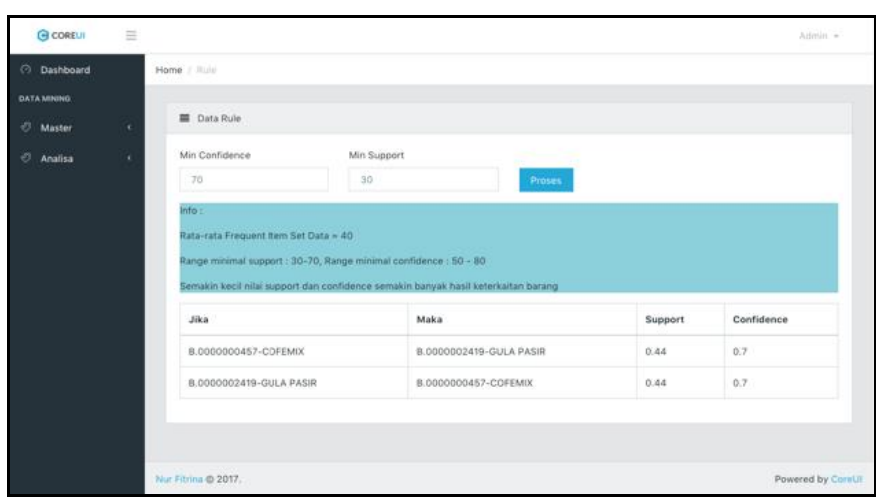

Gambar 8 Halaman Rule

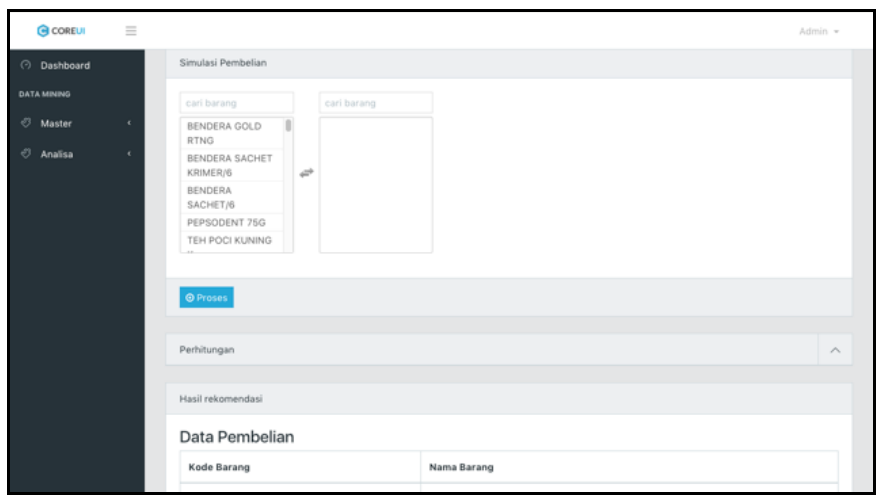

Gambar 9 Halaman Simulasi

\section{Pengujian Sistem}

Pengujian sistem akan dilaksanakan dengan cara pengujian fungsionalitas sistem. Pengujian fungsionalitas sistem dilakukan dengan teknik pengujian black box testing dan uji validitas. Berikut merupakan tabel pengujian BlackBox dari perhitungan apriori.

Tabel 4 Uji BlackBox Rule

\begin{tabular}{|c|c|c|c|}
\hline Test Case & $\begin{array}{l}\text { Hasil } \\
\text { Harapan }\end{array}$ & $\begin{array}{l}\text { Hasil } \\
\text { Keluaran }\end{array}$ & $\begin{array}{l}\text { Hasi } \\
\text { Uji }\end{array}$ \\
\hline $\begin{array}{l}\text { Input } \\
\text { minimal } \\
\text { confidence } \\
\text { dan minimal } \\
\text { support } \\
\text { dengan nilai } \\
0-100\end{array}$ & $\begin{array}{l}\text { Cek besaran } \\
\text { nilai dan } \\
\text { tersimpan di } \\
\text { tabel rule } \\
\text { database } \\
\text { apriori }\end{array}$ & $\begin{array}{l}\text { Data rule } \\
\text { tersimpan } \\
\text { di tabel } \\
\text { rule } \\
\text { database } \\
\text { apriori }\end{array}$ & Sesuai \\
\hline $\begin{array}{l}\text { Input } \\
\text { minimal } \\
\text { confidence } \\
\text { dan minimal } \\
\text { support } \\
\text { dengan nilai } \\
\text { Kosong atau } \\
\text { tidak diisi. }\end{array}$ & $\begin{array}{l}\text { Penolakan } \\
\text { dan muncul } \\
\text { internal error }\end{array}$ & $\begin{array}{l}\text { Muncul } \\
\text { tampilan } \\
\text { internaler } \\
\text { rerror }\end{array}$ & Sesuai \\
\hline
\end{tabular}

Adapun pengujian fungsional sistem dengan teknik Uji validitas adalah seperti terlihat pada Tabel 5. 
Tabel 5 Uji Validitas

\begin{tabular}{|c|c|c|c|}
\hline Data & $\begin{array}{l}\text { Event yang } \\
\text { sudah } \\
\text { berlangsung }\end{array}$ & $\begin{array}{l}\text { Sistem } \\
\text { (Algoritma } \\
\text { Apriori) }\end{array}$ & $\begin{array}{l}\text { Perbedaan } \\
\text { Yang } \\
\text { terjadi }\end{array}$ \\
\hline $\begin{array}{l}\text { Data } \\
\text { Testing }\end{array}$ & $\begin{array}{l}\text { Telur } \\
\text { Indomie } \\
\text { Goreng } \\
\text { Minyak Sawit } \\
\text { Sedap Soto } \\
\text { Gula Pasir } \\
\text { Tepung Terigu } \\
\text { Ct } \\
\text { Susu Sachet } \\
\text { Gold } \\
\text { Samsoe } 12 \\
\text { Djarum Super } \\
12 \\
\text { Teh Nyapu } \\
\text { The Gopek } \\
\text { Gula Wates } \\
\text { Sedap Ayam } \\
\text { bawang }\end{array}$ & $\begin{array}{l}\text { Cofemix } \\
\text { Gula Pasir } \\
\text { Sedap } \\
\text { Ayam } \\
\text { Bawang } \\
\text { Indomie } \\
\text { Goreng } \\
\text { Telur }\end{array}$ & $\begin{array}{l}1 \text { item yang } \\
\text { perlu } \\
\text { ditambahka } \\
\text { n dalam } \\
\text { rekomenda } \\
\text { si yaitu } \\
\text { Cofemix. }\end{array}$ \\
\hline $\begin{array}{l}\text { Data } \\
\text { Training }\end{array}$ & $\begin{array}{l}\text { Telur } \\
\text { Indomie } \\
\text { Goreng } \\
\text { Minyak Sawit } \\
\text { Sedap Soto } \\
\text { Gula Pasir } \\
\text { Tepung Terigu } \\
\text { Ct } \\
\text { Susu Sachet } \\
\text { Gold } \\
\text { Samsoe } 12 \\
\text { Djarum Super } \\
12 \\
\text { Teh Nyapu } \\
\text { Teh Gopek } \\
\text { Gula Wates } \\
\text { Sedap Ayam } \\
\text { bawang } \\
\text { Cofemix }\end{array}$ & $\begin{array}{l}\text { Cofemix } \\
\text { Gula Pasir } \\
\text { Sedap } \\
\text { Ayam } \\
\text { Bawang } \\
\text { Indomie } \\
\text { Goreng } \\
\text { Telur Teh } \\
\text { Nyapu }\end{array}$ & $\begin{array}{l}\text { Tidak ada } \\
\text { lagi } \\
\text { rekomenda } \\
\text { si item } \\
\text { yang belum } \\
\text { terpenuhi. }\end{array}$ \\
\hline
\end{tabular}

Dari hasil pengujian terdapat perbedaan kuantitas. Pada event yang berlangsung kuantitas lebih banyak dari rekomendasi item pada sistem disebabkan karena adanya perbedaan sudut pandang dalam penentuan. Pada event yang berlangsung berdasarkan jumlah pembelian barang selanjutnya.

Sedangkan pada penelitian ini sudut pandang didasarkan pada pola pembelian konsumen sehingga didapatkan prediksi barang yang saling terkait dalam keranjang barang konsumen.

Dari hal tersebut maka sistem dapat menjadi sebuah referensi dalam merekomendasikan barang untuk melengkapi pembelian stok pada event yang berlangsung.

\section{PENUTUP}

\subsection{Kesimpulan}

Adapun kesimpulan yang didapat dari kegiatan penelitian ini adalah sebagai berikut:

- terciptanya sebuah sistem rekomendasi barang untuk pembelian barang dengan menggunakan algoritma apriori.

- Dari pengujiantersebut dapat disimpulkan bahwa algoritma yang digunakan program sesuai dengan perhitungan algoritma apriori. Selain itu dilakukan uji di Minimarket Batox dengan membandingkan rekomendasi sistem menghasilkan adanya perbedaan kuantitas pada jenis barang yang terpilih.

\subsection{Saran}

Sistem rekomendasi barang dengan algoritma apriori ini memiliki kelemahan diantara sistem tidak terintegrasi dengan sistem yang telah berjalan di Minimarket Batok. Algoritma apriori memiliki kelemahan yaitu melakukan scan data yang berulangulang sehingga memori yang terpakai cukup banyak. Penelitian ini dapat dikembangakan pada metode aturan asosiasi lainya, seperti FP-Growth dan Hash Based. Kedua nya diketahui merupakan algoritma pengembangan dari algoritma apriori.

\section{DAFTAR PUSTAKA}

[1] G. I. Marthasari, Y. Azhar, and D. K. Puspitaningrum, "Sistem Rekomendasi Penyewaan Perlengkapan Pesta menggunakan Collaborative Filtering dan Penggalian Aturan Asosiasi," J. SimanteC, vol. 5, no. 1, pp. 1-8, 2015.

[2] D. Larose, Discovering Knowledge in Data: An Introduction to Data Mining (Third Edition). New Jersey: John Wiley \& Sons, 2014.

[3] L. Kusrini, Algoritma Data Mining. Yogyakarta: Andi Offset, 2009.

[4] N. Wandi, "Pengembangan Sistem Rekomendasi Penelusuran Buku dengan Penggalian Association Rule," J. Tek. ITS, vol. 1, pp. 15-20, 2012.

[5] R. Yanto, "Implementasi Data Mining dengan Metode Algoritma Apriori dalam Menentukan Pola Pembelian Obat," Citec J., vol. 2, pp. 46-52, 2015.

[6] R. P. Indahyahni, "Penggunaan Algoritma Apriori untuk Menentukan Rekomendasi Strategi Penjualan pada Toserba DIVA," 
Kediri, 2015.

[7] N. Diahpangastuti, "Sistem Rekomendasi Bidang Minat Mahasiswa Menggunakan Metode Association Rule dan Algoritma Apriori," Surabaya, 2014.

[8] R. M. Anggraeni, "Perbandingan Algoritma Apriori dan Algoritma FP-Growth untuk Rekomendasi pada Tramsaksi Peminjaman Buku di Perpustakaan Universitas Dian Nuswantoro," Semarang, 2015.

[9] D. Listriani, A. H. Setyaningrum, and F. E. M. A, "Penerapan Metode Asosiasi Menggunakan Algoritma Apriori pada Aplikasi Analisa Pola Belanja Konsumen," J. Tek. Inform., vol. 9, no. 2, pp. 120-127, 2016.

[10] I. Fahmi, H. Suyono, and M. Sarosa, "Optimasi Seleksi Aturan Untuk Rekomendasi Bundling Produk Melalui Kombinasi Algoritma Apriori dan Utility Weighted Score ( UWS )," vol. 10, no. 2, pp. 59-62, 2016. 